\title{
Evolving missions and university entrepreneurship: academic spin-offs and graduate start-ups in the entrepreneurial society
}

\author{
Chiara Marzocchi $^{1}{ }_{(\mathbb{D})} \cdot$ Fumi Kitagawa $^{2} \cdot$ Mabel Sánchez-Barrioluengo $^{3}$
}

Published online: 9 September 2017

(C) The Author(s) 2017. This article is an open access publication

\begin{abstract}
A recent call has urged to broaden the conceptualization of university entrepreneurship in order to appreciate the heterogeneity of contexts and actors involved in the process of entrepreneurial creation. A gap still persists in the understanding of the variety of ventures generated by different academic stakeholders, and the relationships between these entrepreneurial developments and university missions, namely, teaching and research. This paper addresses this particular gap by looking at how university teaching and research activities influence universities' entrepreneurial ventures such as academic spin-offs and graduate start-ups. Empirically, we analyse the English higher education sector, drawing on institutional data at the university level. First, we explore the ways in which teaching and research activities are configured, and secondly, we examine how such configurations relate to academic spin-offs and graduate start-ups across different universities over time. Our findings suggest, first, that the evolution of USOs and graduate start-ups exhibit two different pathways over time; and second, that teaching and research both affect entrepreneurial ventures but their effect is different.
\end{abstract}

Keywords Academic entrepreneurship · Graduate start-ups · University spin-offs $\cdot$ Teaching $\cdot$ Research

JEL Classification I23 $\cdot$ L26 $\cdot$ M31

Chiara Marzocchi

chiara.marzocchi@manchester.ac.uk

1 Manchester Institute of Innovation Research, The University of Manchester, Manchester, UK

2 University of Edinburgh Business School, Edinburgh, UK

3 Unit of Human Capital and Employment, Joint Research Centre, European Commission, Ispra, Italy 


\section{Introduction}

The role of the university has evolved over time in response to the forces shaping economic growth (Audretsch 2014). A number of studies on academic entrepreneurship and "university entrepreneurship" (Rothaermel et al. 2007) has acknowledged the high potential of academic entrepreneurial mechanisms as beneficial to the economy and society in general (Feldman and Desrochers 2004; Shane 2004; O'Shea et al. 2005; Wright et al. 2007). However, the role of the university in the entrepreneurial society has been portrayed in a much broader way (Audretsch 2014) and urges to build a wider perspective reflecting the changing roles of universities in order to "embrace greater variety in the extent and nature of academic entrepreneurship" (Siegel and Wright 2015, p 584).

The recent call to rethink academic entrepreneurship derives from the recognition of an undue policy and research interest placed on business ventures linked to the commercialization of research and intellectual property (IP) protection (D'Este and Patel 2007; Grimaldi et al. 2011). There is also an acknowledged need to extend the understanding of the different contexts of entrepreneurship, actors and mechanisms that facilitate a wide range of venture creation (Leitch et al. 2012; Siegel and Wright 2015). Most of the literature tends to focus on research by academic staff, neglecting the role that teaching exerts on business creation (Guerrero and Urbano 2012). Moreover, a broader range of entrepreneurial ventures is emerging from higher education institutions (HEIs) and different stakeholders, notably students and alumni, are becoming more embedded in the process of generation of entrepreneurial opportunities (Libecap 2005; Hsu et al. 2007; Mars et al. 2008; Shah and Pahnke 2014; Link et al. 2014). However, whilst studies suggest that more consideration should be given to both the growing scale and economic relevance of students' start-ups, empirical findings investigating these processes in relation to the organizational contexts of universities remain limited (e.g. Astebro et al. 2012; Guerrero et al. 2016; Bergmann et al. 2016; Beyhan and Findik 2017).

Gaps still persist on both the understanding of the variety of ventures generated by different academic stakeholders, and the relationships between these entrepreneurial developments and universities' missions, namely, teaching and research. This paper addresses this particular gap by looking at how the institutional contexts of university activities, those inherently related to teaching and research, influence university entrepreneurial ventures, focusing on university spin-offs and graduate start-ups.

Before academics and students start a new business, the university provides a range of support mechanisms to develop entrepreneurial ideas, improve strategic planning and gain access to new resources. The university environment itself provides the context where academics and students can access to knowledge through research and teaching, including research projects, scientific publications, research supervisions, and teaching provisions ranging from academic curricula to more specific forms of entrepreneurship education and training. The aim of this work is to improve our understanding of how activities related to teaching and research affect the diversity of entrepreneurial ventures generated at the university level, and asking ultimately whether or not universities with different organization of research and teaching activities should pursue the same goals in terms of business ventures. In order to investigate this further, firstly, we explore the ways in which teaching and research activities are configured within the university, and secondly, we examine how such configurations explain different entrepreneurial outcomes across HEIs. Empirically, we analyse the UK higher education sector, more specifically we focus on the population of English HEIs drawing on longitudinal data on both university spin-offs (USOs) and graduate start-ups. 
The rest of the paper is structured as follows: the next section provides a review of the literature and introduces the theoretical approaches underlying our hypotheses. Section 3 presents backgrounds of the study, data and methodology. The results of the data analysis are discussed in Sects. 4 and 5 reflects on the implications and limitations of our findings and identifies directions for future research.

\section{Theoretical framework and hypotheses}

\subsection{Scope of university entrepreneurship}

Over the last three decades, a broad range of literature surrounding the concepts of "university entrepreneurship" and "academic entrepreneurship" (e.g. Rothaermel et al. 2007; Siegel et al. 2007a, b; Wright 2014) has developed, where the focus has been mostly on spin-offs (USOs) based on university intellectual property. The relevance of activities encompassing the commercialization of research results and the protection and exploitation of intellectual property emanating from universities has been acknowledged as major policy and research drivers towards the promotion of innovation and economic growth (e.g. Geuna and Muscio 2009; Mowery and Sampat 2005; Bercovitz and Feldman 2006). Spinoffs represent a crucial dimension of university entrepreneurship. They involve the development of a business opportunity based on novel technology emerging from academic engagement (Markman et Al. 2008). As such, they reflect a specific entrepreneurial outcome directly linked to the research capacity by university staff to transfer benefits from research to the wider society (Rasmussen et Al. 2011). Several contributions have examined the variety of factors that influence both the generation and success factors of spin-offs activity. These includes national policies, institutional support in the form of specialized and dedicated infrastructures such as incubators, as well as types and composition of entrepreneurial teams (e.g. Siegel et al. 2003; Shane 2004; Lockett et al. 2005; Link and Scott 2005; Niosi 2006; Siegel et al. 2007a, b; Damsgaard and Thursby 2013).

In particular, studies focusing on organizational factors indicate the significance of the entrepreneurial role of technology transfer offices (TTOs), as a key for the success of spinoffs (e.g. Goldstein 2010; Siegel et al. 2003). These include TTOs' expertise and networking capacity, and their ability to recognize opportunities and organize equity ownership for the spin-offs (Lockett and Wright 2005; O'Shea et al. 2005). At the same time, authors have pointed out that economic returns from spin-offs are indeed small and mostly sorted across few institutions (Heher 2006) and that the probability to generate financially rewarding forms of entrepreneurship from technology transfer activities of research alone is on average fairly low (Lester 2005; Mowery et al. 2001; Harrison and Leitch 2010). Indeed, although spin-offs convey an important measure of entrepreneurial output of academic research, reflections on HEIs entrepreneurial capacity should not be confined to these alone (Grimaldi et al. 2011).

The recent shift in perspective on the role of universities has expanded the focus from the analysis of the instruments available to generate entrepreneurship from commercialization of research (such as spin-offs and licensing) to a broader scope and capacity of universities entrepreneurship. Much attention has been devoted to the role of training as an engine to foster entrepreneurial culture and drive forward socio-economic development (Kuratko 2005; European Commission 2006). The role higher education plays in determining the chances of individual graduates' self-employment and new venture creation has 
been acknowledged in a number of entrepreneurship and education literature (e.g. Honig 2004; Béchard and Grégoire 2005; Kuratko 2005; Fayolle 2006, 2013). Growing policy evidence suggests a positive association between the magnitude of students' entrepreneurship and the performance of the regional and national economy as the number of HEIs using their initiatives to stimulate graduate enterprise and entrepreneurship increases (European Commission 2012, 2015; GEM 2012).

However, it has been pointed out that the literature on graduate entrepreneurship often neglects the contextual nature of such activities (Greene and Saridakis 2008). Recent studies are beginning to shed light on the contextual characteristics driving entrepreneurial choices by highlighting different organizational, institutional and regional contexts that influence graduate start-ups and venture creation (Astebro et al. 2012; Leitch et al. 2012; Dodd and Hynes 2012; Bergmann et al. 2016; Walter and Dohse 2012). University organizational capabilities, resources and ultimately the knowledge generated by the contextual characteristics associated to research and teaching, affect the entrepreneurial competences of graduate entrepreneurs, and determine the institutional capacity to generate student ventures (Beyhan and Findik 2017). Shah and Pahnke (2014, p. 782) identify two key dimensions of knowledge which contribute to university entrepreneurship. One is innovative knowledge which provides the understanding of a particular technology and serves as the basis for commercial opportunities, while the other is entrepreneurial knowledge and provides an understanding of the entrepreneurial processes and networks from which to draw resources and expertise, including those gained by students while pursuing their education. Building on this, with an aim to probe the influence of teaching and research on university entrepreneurial activities, we hypothesize that:

H1 Both teaching and research activities exert an influence on entrepreneurial ventures.

\subsection{University context and entrepreneurship}

According to the different practices and contextual characteristics they adopt, universities can be considered as hybrid organizations where competing demands and institutional logics coexist and lead to heterogeneous pathways and outcomes (Powell and Colyvas 2008; Ocasio and Radoynovska 2016). Universities have historically balanced the combination of such pathways in order to adapt and respond to external pressures and accomplish their multiple missions. As a result, at the individual university level, universities scale and combine their activities to reflect broader higher education dominant logics associated with teaching and research missions respectively.

This conceptualization closely relates to recent developments on the entrepreneurial university model (Guerrero and Urbano 2012; Abreu et al. 2016), where perceived interlinkages between teaching, research, and knowledge exchange activities interact and nurture academic entrepreneurship (Abreu and Grinevich 2013; Healey et al. 2014; Siegel and Wright 2015). Many studies have looked at entrepreneurial ventures differentiating between research-led and teaching-led universities. For instance, Abreu et al. (2016) analyses the entrepreneurial practices by academic staff and show that teaching-led universities engage better at the local level and in less formal types of ventures, while research-led HEIs perform better internationally and in more traditional commercialisation activities. It is also suggested that teaching-led universities exert a capacity to promote academic entrepreneurship and technology clusters (Calzonetti et al. 2012; Braunerhjelm and Helgesson 2006) due to their proactive leadership in regional capacity building and networking, rather than on "pushing" innovations via the formal knowledge- 
commercialization routes (Abreu et al. 2016). Greene and Saridakis (2008) showed that in the UK pre-1992 universities (generally research focussed) are more likely to be positively associated with initial self-employment of their graduates. Hewitt-Dundas (2012) uses a cluster analysis of UK universities based on research performance indicators, identifying two clusters of high and low research-intensive universities. Abreu et al. (2009) analyse the knowledge exchange performance of the Russell Group Universities, other established universities formed before 1992, post-1992 universities and others.

These studies inform our understanding of the variety across HEIs, but they tend to adopt a restrictive perspective on what teaching and research capacity entails and how those affect HEIs. First, they tend to apply a dichotomous categorization of research-led versus teaching-led universities not considering the dynamic changes of universities over time (Sánchez-Barrioluengo et al. 2016). Second, the studies above either underplay the role of teaching in relation to graduates' business ventures or do not consider such ventures focussing exclusively on staff entrepreneurial outcomes.

Naturally, universities' teaching and research activities and the entrepreneurial ventures they generate are further conditioned by other factors. Notably, universities with different organizational heritage play different roles, reflecting diverse institutional priorities, cultures and governance structures, and also a different mix of discipline areas and research intensity (Perkmann et al. 2011; Hewitt-Dundas 2012; Abreu and Grinevich 2013; Abreu et al. 2016). They are influenced by the university strategies and reward systems (Huyghe and Knockaert 2015); but also by the disciplinary composition and the research quality of their staff (Abreu et al. 2016). It is argued that organizations with the capacity to pursue entrepreneurial strategies are in the positions to systematically recognize and exploit entrepreneurial opportunities (Eisenhardt et al. 2000) as they define and set specific actions and outcomes to reach their objectives (Ireland et al. 2009).

Studies have found that the availability of resources (stock of technologies and skilled staff), incentives and rewards systems, business development competences and the ability to access external finances and networks are the main factors that facilitate the formation of spin-off companies in universities (Lockett et al. 2003; Ismail et al. 2010; Lockett et al. 2005). These entrepreneurial opportunities rest on the knowledge generated at universities (Shah and Pahnke 2014). As well as considering the knowledge from research related resources (research endowments), there is a need to broaden the conceptual understanding of the links between knowledge, skills and networks gained by students while pursuing their education provisions (teaching endowments).

We use the term 'endowment' to identify the combination of contextual characteristics related to teaching and research, and representing the value that universities place on them as part of their institutional mission. The institutional context, as defined by the unique combination of teaching and research endowments, including the structures and practices at different institutional environments in response to HEIs' teaching and research missions, affect the capacity to pursue different entrepreneurial ventures. HEIs driven by research reflect logics linked to competitive research grants, and collaborative research activities with industry and their entrepreneurial scope will arguably favour business ventures protecting the governance of science-generated knowledge, e.g.: licensing of technology and spin offs creation (Colyvas and Powell 2007). Following this, we hypothesize that:

H2 The effect of teaching and research endowments on business ventures is different, and specifically: 
H2a Greater availability of knowledge from research activities (research endowments) positively influences spin-offs but not graduate start-ups.

H2b Greater availability of knowledge from teaching activities (teaching endowments) positively influences graduates start-ups but not spin-offs.

\section{Background, data and methodology}

The following sections provide some background on the higher education sector and university entrepreneurship policies in the UK and England and then move to describe the sources of data as well as main variables and statistical methods used for the analysis.

\subsection{Higher education institutions and university entrepreneurship policies in England and the UK}

In the UK, higher education policy is a devolved matter across England, Scotland, Wales and Northern Ireland. Given the devolution of the Higher Education sector and the related differences in sources of funding and policy initiatives across England, Scotland, Wales and Northern Ireland, this paper focuses on the higher education sector in England alone.

The Higher Education Funding Council for England (HEFCE) is the main funding body for the English HEIs and provides resources to support universities' knowledge exchange and entrepreneurship activities (Kitagawa and Lightowler 2013; Rossi and Rosli 2015). In England, the Higher Education Funding Council (HEFCE) has funded 'third stream' initiatives since the late 1990s, initially through the Higher Education Reach Out to Business and the Community initiative (HEROBC) and since 2001 through the Higher Education Innovation Fund (HEIF). Over the last decade, the government aimed to support the development of the long-term institutional strategies for entrepreneurial activities by providing a stable stream of funding for the universities.

The UK government policy has emphasised the links between universities and economic development since the late 1990s (DTI 1998). The creation of academic spin-off firms was particularly promoted after the Lambert Review of Business-University Collaboration (Lambert 2003) by addressing issues of commercialization and institutional constraints on Intellectual Property Rights (IPRs). There are also growing concerns that the focus of universities and of policy-makers has been on the number, rather than on the quality and commercial viability, of these university spin-off firms (Harrison and Leitch 2010).

Since the early 2000s, a number of initiatives have been implemented at the UK level to stimulate university enterprise and entrepreneurship in a broader sense (BIS 2013) and to contribute to the development of entrepreneurial and enterprising staff, students and graduates (Smith 2015). The UK government has particularly focused on encouraging more graduates to pursue entrepreneurial career paths (HM Treasury and BERR 2008; Young 2014); and creating a joined approach across industry, government and HEIs to respond to societal and economic challenges and to develop entrepreneurial environments within and beyond HEIs (CIHE/NCGE/NESTA 2008). Examples include initiatives designed to increase the number of students undertaking entrepreneurship modules (Enterprise in Higher Education initiative), the allocation of resources to establish twelve regional Science Enterprise Challenge Centres across the UK funded by the Office of Science and Technology in early 2000s. 


\subsection{Data and sources of information}

This analysis is drawn on a longitudinal database that combines evidence from the Higher Education Business Community Interaction (HE-BCI) Survey and other data from the Higher Education Statistical Agency (HESA). The aggregate information covers the full population of English universities $(\mathrm{N}=163)$ for six academic years (from 2008-2009 to 2013-2014).

Since 2000, the HE-BCI annually collects administrative data from the UK HEIs on the income generated through university-led knowledge exchange activities, ranging from the commercialization of new knowledge, to the delivery of professional training, consultancy and other activities with a direct social benefit (HEFCE 2015; Smith 2015). The data has been collected by the HESA as part of the Finance Statistics Return (FSR), the main source of financial information on the total activities of all UK HEIs (HEFCE 2017). In England, the Funding Council uses certain elements of the HE-BCI returns as part of the funding formulae that determines the allocation of the Higher Education Innovation Fund (HEIF) for each university. The HE-BCI collects information on universities' entrepreneurial venture outcomes, including university spin-offs (USOs) and graduate start-ups. In addition to the financial data, the HE-BCI survey collects information on structures and support mechanisms available at HEIs for knowledge exchange activities. Interpretation of the HE-BCI data needs some caution due to problems of internal consistency particularly for the first editions of the survey (1999-2000 to 2003-2004). Despite this, it is acknowledged that the HE-BCI provides the most complete and extensive longitudinal data on university venture activities at the national level in the UK (Smith 2015).

Our database draws on relatively recent sets of data from the HE-BCI (2008/ 2009-2013/2014), which is then complemented by further information on universities' characteristics drawn from other data available from the Higher Education Statistical Agency (HESA). These include data regarding students (undergraduates and postgraduates), as well as staff composition and distribution in relation to research and teaching allocation of their time.

\subsubsection{Dependent variables: university spin-offs and graduate start-ups}

Our dependent variables represent two types of university entrepreneurial venture: academic spin-offs (USOs) and graduate start-ups. The HE-BCI provides definitions for both academic spin-offs and graduate start-ups in order to assure consistency and homogeneity across the data submitted by the single universities (HESA 2015). USOs are companies setup to exploit IPR originated from within the HEI and where the HEI continues to have some ownership. Graduate start-ups include all new business started by recent graduates (within 2 years after the graduation) regardless of where any IPR resides, but only where there has been formal business and/or enterprise support from the HEI. Also, before being officially included in the HE-BCI statistics, graduate start-ups must have achieved legal registration with the tax office (e.g. with HM revenue and customs).

Figure 1 shows the different patterns of these entrepreneurial outcomes. Specifically, the figure illustrates the evolution of new and active USOs and graduate start-ups returned by English universities between the academic year 2008/2009 and 2013/2014.

The evolution of the two types of entrepreneurial ventures indicates that different dynamics have been taking place during the time period considered. USOs have registered 

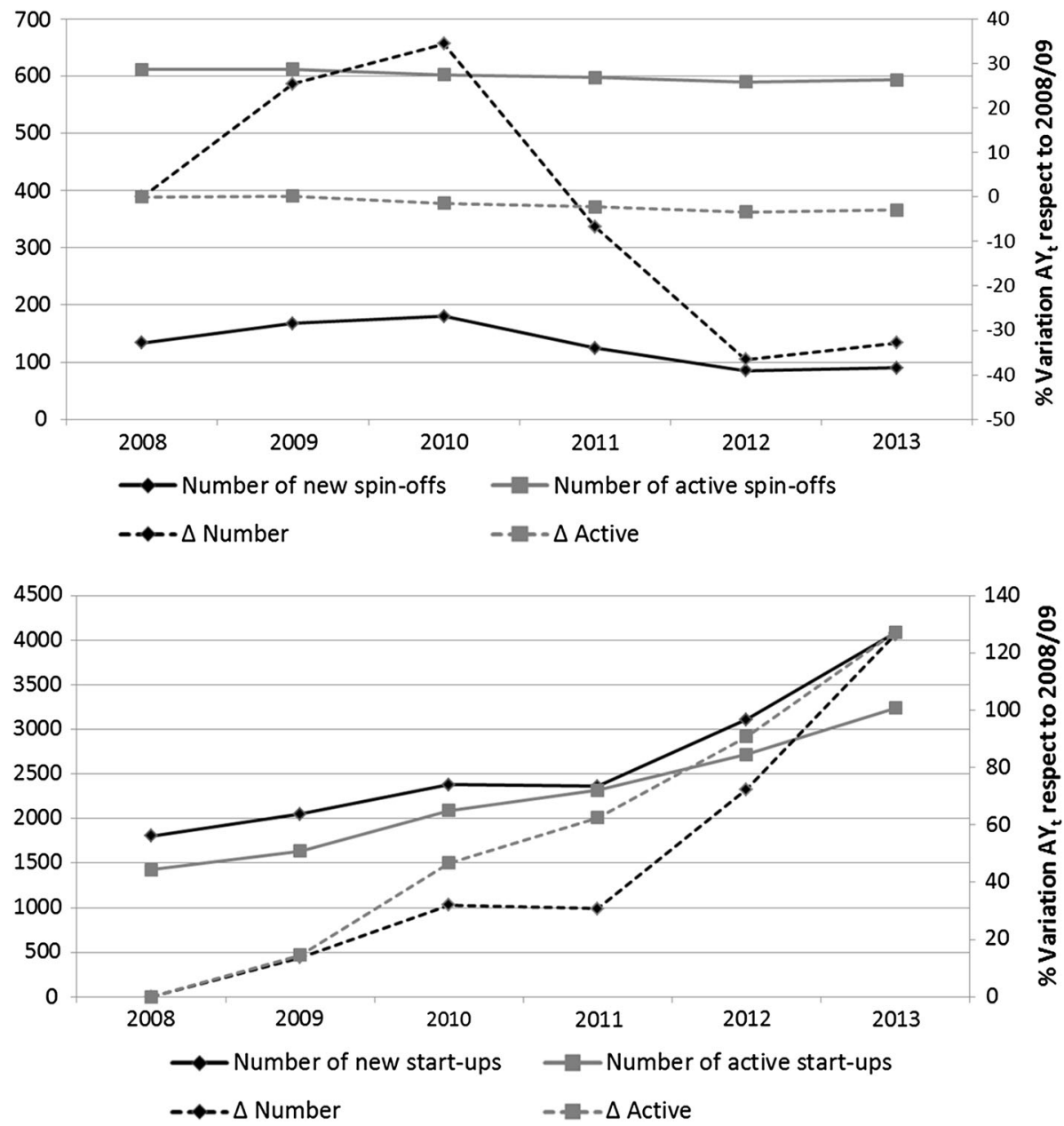

Fig. 1 Evolution of spin-offs and start-ups in English HEIs (2008-2013). Note Increments read on the right axes. Increments are calculated as $\Delta=\left(\mathrm{t}-\mathrm{t}_{0}\right) / \mathrm{t}_{0}$ where $\mathrm{t}_{0}$ is $2008 / 2009$

a contraction (both in terms of growth rate $^{1}:-11.5 \%$; and number of active firms: $-0.8 \%$ ), whilst graduate start-ups have been consistently increasing (15.8\% of new firms; and $16 \%$ of active firms).

In order to distinguish between a short and long-term effect of teaching and research endowments on entrepreneurial ventures, for the purpose of the analysis we collated data by individual institutions on: (1) total number of new companies created within the reporting period (Creation) as a proxy of an entrepreneurial output; and (2) the current turnover of all active firms ( $£ 000 \mathrm{~s}$ ) (turnover) as a proxy of an entrepreneurial outcome.

\footnotetext{
${ }^{1}$ The average annual growth rate is calculated by dividing the slope by the income. The slope is determined by the regression line formed by the matrix corresponding to the years of study 2008/09-2013/14 and number of spin-offs and start-ups raised by the universities.
} 


\subsubsection{Independent variables: teaching and research endowments}

Our two main independent variables relate to the teaching and research characteristics that define respectively teaching and research endowments. These endowments represent the combination of different activities related to teaching and research and thus they are treated not as discrete but as a combined spectrum. We define teaching and research endowments according to a set of variables capturing both university resources and university activities. In terms of resources we include both teaching and research funding allocation (e.g.: how much funding the individual university receives given the number of enrolled students, and the amount of funding the university obtains from competitive research), as well as the number of staff. In terms of university activities we include information on undergraduate and postgraduate students and the results of the research excellence framework (REF) as a measure of the assessment in the quality of research. A detailed definition of all the variables included is presented in Table 1 .

In order to prove the adequacy and the uniqueness of the proposed variables capturing teaching and research endowments, we run factor analyses for each year of the time period considered. Specifically, we use a principal components analysis with a Varimax rotation (with Kaiser normalization), and extract factors at the 1.0 or greater eigenvalue level. The results of the rotated matrix are robust and stable across all the years analysed (from AY 2008/2009 to AY 2013/2014) and confirm that research and teaching activities combine in two main factors, corresponding to teaching and research endowments (Table 2). We use the factor scores from the factor analyses for each particular year to express our main independent variables representing Teaching (TE) and Research (RE) endowments across universities in England. Teaching endowments reflect universities activities strongly associated to teaching logics, and the internal consistency is mostly related to teaching funding and undergraduate students. Conversely, research endowments seem to be mostly loaded by activities related to research and particularly by research funding and staff in research activities.

\subsubsection{Control variables}

We select a range of control variables to reduce the observed heterogeneity across the sample and minimize bias in the results. We select activities at the university level supporting entrepreneurship, trying to capture institutional level characteristics that determine differences in the chances to develop entrepreneurial ventures across universities. Specifically we include information about the specialization of the university, the availability of infrastructures for entrepreneurial activities, the existence of specific entrepreneurship training activities, the availability of a strategic business plan and a specific variable to control for university size using transparent approach to costing (TRAC) groups. All of them are explained below.

University specialization Specialization by areas and subject domains at individual HEIs has a strong impact on the heterogeneity of the higher education system, not only at the European and national level, but also in terms of differences between institutions (Van Vught 1996, 2008). Adopting a similar approach to Rossi (2009), we use a HerfindahlHirschman index to analyse the subject specialisation of universities in England. The index represents the concentration of area specializations within HEIs. In order to determine such areas we use information on the Cost centres per HEIs showing the share of staff (full-time 
Table 1 Components of research and teaching endowments in HEIs-definitions

\begin{tabular}{|c|c|c|}
\hline Variable & Definition & Source \\
\hline Teaching funding & $\begin{array}{l}\text { Finance return ( } £ 000 \mathrm{~s}) \text {. Income from funding body grants for HE provision } \\
\text { related to Teaching activities and total tuition fees and education contracts }\end{array}$ & HESA \\
\hline Research funding & $\begin{array}{l}\text { Finance return ( } £ 000 \mathrm{~s}) \text {. Income from funding body grants for HE provision } \\
\text { related to Research activities }\end{array}$ & HESA \\
\hline REF & $\%$ of $4 *$ departments in the REF 2014 & HEFCE \\
\hline $\begin{array}{l}\text { Staff in research } \\
\text { activities }\end{array}$ & Number of full-time-equivalent employees in research only activities & HESA \\
\hline $\begin{array}{l}\text { Staff in teaching } \\
\text { activities }\end{array}$ & Number of full-time-equivalent employees in teaching only activities & \\
\hline $\begin{array}{l}\text { Undergraduate } \\
\text { students }\end{array}$ & $\begin{array}{l}\text { Number of full-time-equivalent students in undergraduate and 1st degree } \\
\text { programs (taught) from UK, EU and no-EU countries }\end{array}$ & HESA \\
\hline $\begin{array}{l}\text { Postgraduate } \\
\text { students }\end{array}$ & $\begin{array}{l}\text { Number of full-time-equivalent students in postgraduate programs (taught) } \\
\text { from UK, EU and no-EU countries }\end{array}$ & \\
\hline
\end{tabular}

Table 2 Results of the factor analysis (rotated matrix) in 2008/2009 and 2013/2014

\begin{tabular}{|c|c|c|c|c|c|c|c|c|c|c|c|c|}
\hline & \multicolumn{2}{|c|}{$2008 / 2009$} & \multicolumn{2}{|c|}{$2009 / 2010$} & \multicolumn{2}{|c|}{$2010 / 2011$} & \multicolumn{2}{|c|}{$2011 / 2012$} & \multicolumn{2}{|c|}{$2012 / 2013$} & \multicolumn{2}{|c|}{$2013 / 2014$} \\
\hline & $\mathrm{TE}$ & $\mathrm{RE}$ & $\mathrm{TE}$ & RE & $\mathrm{TE}$ & $\mathrm{RE}$ & $\mathrm{TE}$ & $\mathrm{RE}$ & TE & $\mathrm{RE}$ & $\mathrm{TE}$ & $\mathrm{RE}$ \\
\hline $\begin{array}{l}\text { Research excellence } \\
\text { framework (REF) }\end{array}$ & & 0.59 & & 0.58 & & 0.58 & & 0.58 & & 0.58 & & 0.59 \\
\hline Teaching funding & 0.91 & & 0.90 & & 0.88 & & 0.89 & & 0.85 & & 0.84 & \\
\hline Research funding & & 0.97 & & 0.97 & & 0.97 & & 0.96 & & 0.97 & & 0.96 \\
\hline $\begin{array}{l}\text { Staff in research } \\
\text { activities }\end{array}$ & & 0.95 & & 0.96 & & 0.96 & & 0.95 & & 0.95 & & 0.95 \\
\hline $\begin{array}{l}\text { Staff in teaching } \\
\text { activities }\end{array}$ & 0.61 & & 0.62 & & 0.71 & & 0.67 & & 0.75 & & 0.77 & \\
\hline Postgraduate students & 0.73 & & 0.74 & & 0.69 & & 0.73 & & 0.66 & 0.51 & 0.69 & 0.51 \\
\hline Undergraduate students & 0.97 & & 0.97 & & 0.97 & & 0.96 & & 0.95 & & 0.94 & \\
\hline
\end{tabular}

Varimax rotation and Kaiser Normalization applied. Rotated matrix presents values of factors loadings above 0.5 . TE and RE refer to teaching and research endowments respectively

equivalent) per field using nine cost centres. ${ }^{2}$ Cost centres group staff members to specific discipline area avoiding double counting of staff allocations. As such, considering the number of full-time equivalent staff per Centre group $\left(\mathrm{x}_{\mathrm{i}}\right)$, the index provides a measure of the magnitude of the disciplinary area within the university:

$$
a_{i}=\frac{x_{i}}{\sum_{j=1}^{N} x_{j}}
$$

The information on the size of the cost centres within the single university is then linearly added in order to calculate a measure of the university specialization as:

\footnotetext{
${ }^{2}$ The nine Cost centre considered are: Medicine, dentistry and health; Agriculture, forestry and veterinary science; Biological, mathematical and physical sciences; Engineering and technology; Architecture and planning; Administrative, business and social studies; Humanities and language based studies and archaeology; Design, creative and performing arts; Education.
} 


$$
H=\sum_{j=1}^{N} a_{i}^{2}
$$

This index takes values between 0 and 1, with values closer to zero representing a much diversified portfolio (or low concentration) of area specialisations within the university.

Entrepreneurial infrastructures The existence of internal structures such as TTOs or incubators has been recognised as important assets for commercialization activities (Goldstein 2010) and is considered critical organizational factor (Siegel et al. 2003) as well as expression of the university's capacity and likelihood to promote entrepreneurship. In order to control for the availability of these infrastructures, we create a dummy variable with the value 1 if the university has incubators (on-campus or in the locality) and/or a scientific park accommodation and 0 otherwise. On-campus/other incubators are defined as small office areas used as launch-pads for business ideas from students, staff and alumni that provide a mentoring environment and easy access to facilities. Similarly, science park accommodations include high-specification, purpose built accommodations for start-ups or expanding companies, aimed at scientific research, technology, environmental, engineering, ICT and other knowledge sectors. This information is extracted from the Part A of the HE-BCI survey.

Entrepreneurship training We capture the availability of entrepreneurship training activities available in English universities by drawing on the data available in the Part A of the HE-BCI survey. Specifically, we look at whether or not universities offer support for USOs and graduate start-ups through entrepreneurship training, either provided by the HEI or in collaboration with a partner organization. It should be noted that this is bespoke training for entrepreneurs and is different from the entrepreneurship education provided as part of the regular curriculum. Using this information we build a dummy variable with the value 1 if the university reports offering such extra-curricular training activities related to entrepreneurship and 0 otherwise.

Strategic business plan We consider the strategic business plans developed by HEIs and collect information about commercialization and engagement activities as a signal of the university's capacity to define and foster its entrepreneurial strategy. Using information from the Part A of the HE-BCI survey, we create a dummy variable taking the value of 1 if the university has developed a strategic plan for business support and 0 otherwise.

Size We control for a potential size effect, e.g.: if larger universities tend to show a greater number of entrepreneurial ventures because of a greater availability of resources to invest in entrepreneurial activities. In order to control for the HEI's size, we use information collected via the TRAC Groups (HEFCE 2015). TRAC Groups are based on "transparent approach to costing" criteria and cluster universities according to financial information comparing research income to the total income generated by the HEI per academic year. This provides a framework that "facilitates the production of high quality, comparable information on the cost of activities across the UK HE sector" (BUFDG 2013). TRAC Groups are adjusted periodically in order to reflect changes in universities' funding streams' capacities. The last TRAC return information for the period 2013-2014 (with references to income data of 2012-2013) identifies the following Peer Groups:

According to the Table 3 we generated a categorical variable, sorting universities within the corresponding TRAC group. 
Table 3 TRAC groups-distribution

\begin{tabular}{ll}
\hline TRAC group & Criteria \\
\hline Peer group A & $\begin{array}{c}\text { Institutions with a medical school and research income* of 20\% or more of } \\
\text { total income }\end{array}$ \\
Peer group B & All other institutions with research income* of $15 \%$ or more of total income \\
Peer group C & $\begin{array}{l}\text { Institutions with a research income* of between } 5 \% \text { and } 15 \% \text { of total income } \\
\text { Institutions with a research income* less than 5\% of total income and total } \\
\text { income greater than } £ 150 \mathrm{M}\end{array}$ \\
Peer group D & $\begin{array}{l}\text { Institutions with a research income* less than } 5 \% \text { of total income less than or } \\
\text { equal to } £ 150 \mathrm{M}\end{array}$ \\
Peer group F & Specialist music/arts teaching institutions \\
\hline
\end{tabular}

* Research income is defined as the funding council recurrent research grant plus the total research grants and contracts returned in the HESA Finance Statistics Return (FSR)

Active spin-offs and graduate start-ups To further prevent the size of the university to affect the results of the analysis, we control for the number of active spin-offs and graduate start-ups in order to reduce the bias which a greater availability of research or teaching capacity will have on the likelihood to generate more spin-offs and graduate start-ups respectively.

Table 4 presents results of the correlation matrix and identifies no multicollinearity problems among the variables. In addition, the table includes descriptive statistics of the variables discussed above and included in the model.

\subsection{Statistical methods}

In order to capture the factors affecting the entrepreneurial outcomes of universities, we measure USOs and graduate start-ups in terms of creation and turnover. The first indicator (creation) is a count variable. Given the attention drawn by the empirical literature to the risks associated to analyse such variables, our preferred specification is a Poisson model for panel data (Wooldridge 2010; Cameron and Trivedi 2001). Our choice takes into account the advantages of Poisson over Negative binomial models, particularly that Poisson models provide consistent estimates of the coefficients of interest even when the underlying distribution of the dependent variable is not Poisson (Gouriéroux et al. 1984; Wooldridge 1999). Moreover, even in a longitudinal framework as the one considered here, Poisson estimators have been shown to be robust to a number of misspecifications, such as: overdispersion (it can be accommodated by using robust standard errors); the presence of an excessive number of zeros; and dependence over time (Bertanha and Moser 2016). Taking into account that our dependent variable is zero-inflated, we use robust standard errors clustered. The turnover variable is a quantitative measure left-skewed. In order to obtain non-skewed variables, we apply logarithms and then estimate our results using a fixed effects Ordinary Least Squares regression with robust standard errors. 


\section{Results}

\subsection{Descriptive results}

Our descriptive results focused on the evolution of USOs and graduate start-ups over time in terms of creation and turnover are presented in Fig. 2. In the period considered the creation of USOs shows lower figures than those of graduate start-ups. Specifically, on average only 0.82 and 0.55 new USOs were created in AY 2008/2009 and AY 2013/2014 respectively, compared to an average of 11.1 and 25 new graduate start-ups in the same two periods considered. With respect to turnover however, USOs figures are significantly higher than those of graduate start-ups. In this case, while the average turnover from spinoffs is more than $£ 2000$ thousand, the monetary output of graduate start-ups locates around $£ 650$ thousands (average values for independent variables are available Table 4).

In relation to the independent variables included in our analysis, we can see that on average English HEIs present a specialisation index of 0.34 that highlights that academic staff is fairly equally distributed across subjects. Also, on average English HEIs appear to be inclined to adopt entrepreneurial mechanisms, with $68.6 \%$ of the universities showing to offer entrepreneurial infrastructures; $77.8 \%$ providing bespoke training related to entrepreneurship; and $80 \%$ having included a business plan as part of their strategy. In addition, there is an important difference between the number of active USOs and start-ups in the studied period with less than 5 ventures in the first case and more than 35 in the second one (on average).

\subsection{Regression results}

Table 5 presents the results of our specifications looking at both the number of new companies created per year (Creation: Column I) and the turnover generated by all active firms (Turnover: Column II) across USOs and graduate start-ups. Considering that teaching and research endowments will not have an immediate effect on entrepreneurial ventures, we lag the impact of the two main independent variables in the model of 1 year.

Overall, the results support our hypotheses. Research and teaching endowments have an effect on both USOs and graduate start-ups (H1) with some existing differences on their impact depending on the type of venture considered (H2). Endowments in research significantly support USOs creation but have no effect on new graduate start-ups (Columns I). The availability of infrastructures such as incubators or science parks affects the creation of USOs and has no impact on graduate start-ups. University's specialisation by area domain sorts a negative effect on spin-offs creation reflecting that for spin-offs variety of knowledge domains rather than specialisation might improve the chances to generate new ventures. Finally, the provision of bespoke entrepreneurship training by the university negatively affects the creation of new graduate start-ups, but has no effect on USOs. There are possible different interpretations on this result. Specific entrepreneurship training may give graduates better understanding of the risks and challenges of starting up, which may discourage their actual start-up activities. Academic USOs may have access to other forms of bespoke support mechanisms provided by other organisations such as TTOs.

In relation to turnover (Column II), both graduate start-ups and academic spin-offs are negatively affected by research endowments. However, universities' endowments in teaching positively influence the turnover of graduate start-ups, while negatively affecting returns for spin-offs. The effect of university specialization by area domain is very 


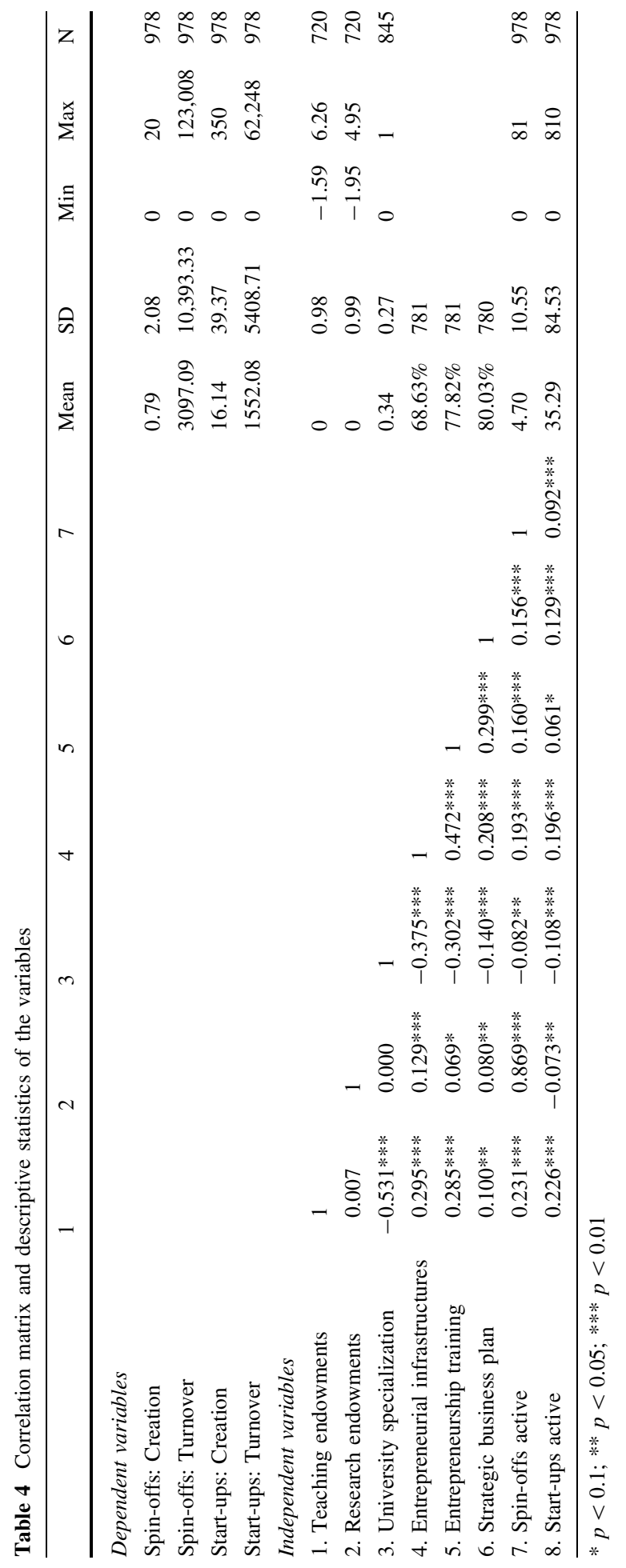




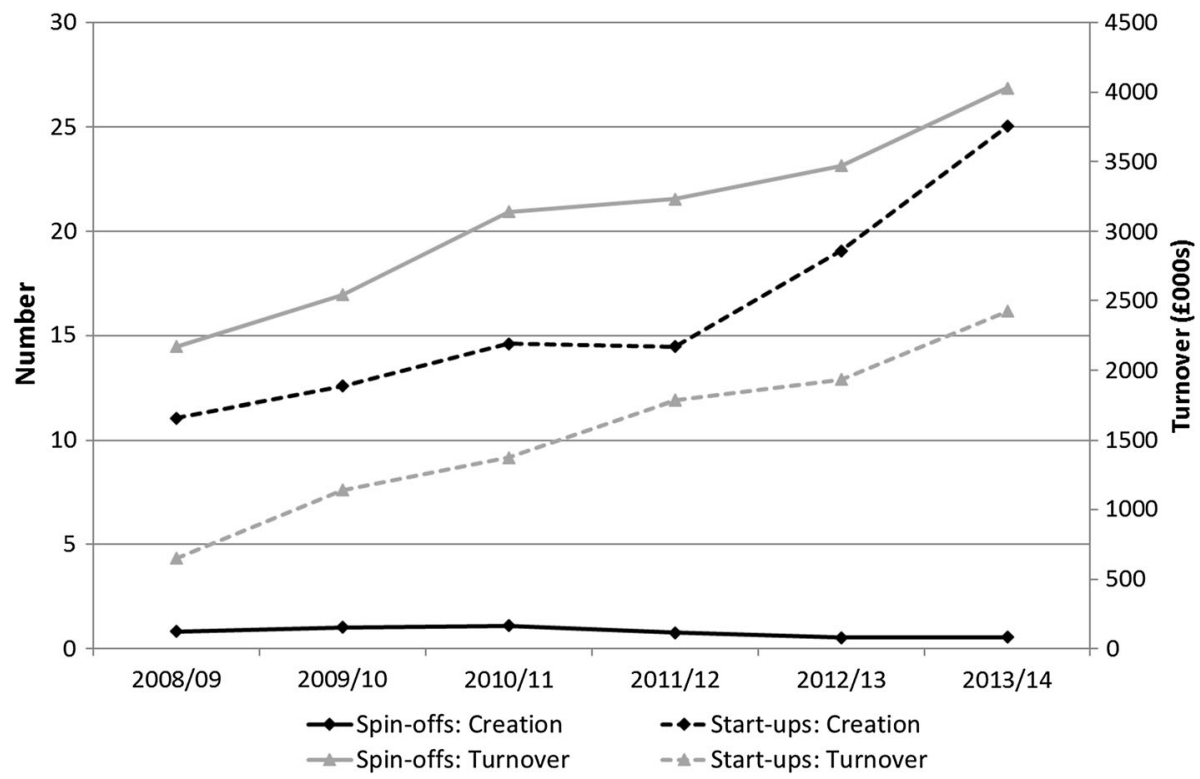

Fig. 2 Evolution of spin-offs and start-ups: creation and turnover. Note Spin-offs and graduate start-ups creation on the left axis; turnover (£000) on the right axis

significant and negative for both the entrepreneurial venture activities. The strategic business orientation of the university positively affects both USOs and graduate start-ups. University infrastructures and entrepreneurship education however are relevant and positively affect only graduate start-ups but have no effect on USOs' turnover. This may suggest that the availability of specific infrastructures (such as incubators) and enduring entrepreneurship training is more relevant for graduate ventures. Finally, the number of current active spin-offs and start-ups positively affect turnover for both types of ventures.

In sum, the effect of teaching endowments positively relates to the returns generated by graduate start-ups but it is negative for turnover. Conversely, the impact of research endowment is more diverse. Research endowments at the university level have no effect on the chances to generate new student ventures, and negatively impact on successful financial returns by graduate start-ups. On the other hand, research endowments do positively relate to the creation of spin-offs ventures, but its effect becomes negative once linked to turnover.

\section{Conclusions and discussion}

In recent years, an increasing recognition has been placed on the broadened scope and nature of academic entrepreneurship, and the diverse ways that universities engage in these activities (Siegel and Wright 2015). Furthermore, the paradigm shift towards the "entrepreneurial society" is noted where the university needs to design new structures to ameliorate tensions arising between traditional research and teaching, and different forms of entrepreneurial endeavours in order to enhance "entrepreneurship capital" (Audretsch 2014 , p. 313) in a variety of institutional contexts. In this light, this paper aimed to 
Table 5 Spin-off and graduate start-ups

\begin{tabular}{|c|c|c|c|c|}
\hline & \multicolumn{2}{|l|}{ Spin-offs } & \multicolumn{2}{|l|}{ Start-ups } \\
\hline & (I) Creation & (II) Turnover & (I) Creation & (II) Turnover \\
\hline Teaching endowments $(t-1)$ & $\begin{array}{l}-0.394 \\
(0.249)\end{array}$ & $\begin{array}{l}-0.366^{* * *} \\
(0.165)\end{array}$ & $\begin{array}{l}0.570 \\
(0.457)\end{array}$ & $\begin{array}{l}0.515 * * * \\
(0.147)\end{array}$ \\
\hline Research endowments $(\mathrm{t}-1)$ & $\begin{array}{l}0.445^{* *} \\
(0.212)\end{array}$ & $\begin{array}{l}-0.716 * * \\
(0.317)\end{array}$ & $\begin{array}{l}0.759 \\
(1.040)\end{array}$ & $\begin{array}{l}-0.609 * * * \\
(0.228)\end{array}$ \\
\hline University specialisation & $\begin{array}{l}-2.614 * * * \\
(0.930)\end{array}$ & $\begin{array}{l}-2.320 * * * \\
(0.766)\end{array}$ & $\begin{array}{l}0.500 \\
(0.388)\end{array}$ & $\begin{array}{l}-3.305^{* * * *} \\
(0.663)\end{array}$ \\
\hline Entrepreneurial infrastructures & $\begin{array}{l}0.726 * * \\
(0.283)\end{array}$ & $\begin{array}{l}0.337 \\
(0.278)\end{array}$ & $\begin{array}{l}-0.021 \\
(0.122)\end{array}$ & $\begin{array}{l}1.059 * * * \\
(0.319)\end{array}$ \\
\hline Entrepreneurship training & $\begin{array}{l}0.082 \\
(0.239)\end{array}$ & $\begin{array}{l}0.241 \\
(0.307)\end{array}$ & $\begin{array}{l}-0.486 * * * \\
(0.0937)\end{array}$ & $\begin{array}{l}0.831 * * \\
(0.356)\end{array}$ \\
\hline Strategic business plan & $\begin{array}{l}-0.575 \\
(0.415)\end{array}$ & $\begin{array}{l}0.630 * * \\
(0.294)\end{array}$ & $\begin{array}{l}-0.156 \\
(0.203)\end{array}$ & $\begin{array}{l}0.661 * * \\
(0.282)\end{array}$ \\
\hline Active spin-offs & & $\begin{array}{l}0.173 * * * \\
(0.032)\end{array}$ & & \\
\hline Active start-ups & & & & $\begin{array}{l}0.0165 * * * \\
(0.002)\end{array}$ \\
\hline Constant & $\begin{array}{l}-18.57 * * * \\
(5.694)\end{array}$ & $\begin{array}{l}4.935 * * * \\
(0.623)\end{array}$ & $\begin{array}{l}0.431 \\
(3.661)\end{array}$ & $\begin{array}{l}2.702 * * * \\
(0.629)\end{array}$ \\
\hline Year & $\mathrm{FE}$ & $\mathrm{FE}$ & $\mathrm{FE}$ & $\mathrm{FE}$ \\
\hline TRAC groups & $\mathrm{FE}$ & $\mathrm{FE}$ & $\mathrm{FE}$ & $\mathrm{FE}$ \\
\hline \multicolumn{5}{|l|}{ Ln alpha } \\
\hline Constant & $\begin{array}{l}0.729 \\
(0.993)\end{array}$ & & $\begin{array}{l}1.227 * \\
(0.720)\end{array}$ & \\
\hline $\mathrm{R}^{2}$ & & 0.583 & & 0.426 \\
\hline $\mathrm{N}$ & 570 & 575 & 570 & 575 \\
\hline
\end{tabular}

Robust Standard errors; * $p<.1$; ** $p<.05$; *** $p<.01$; Column (I): Poisson regression (clustered ID); Column (II): OLS (robust SE). The 1-year lag introduced in the regressions limits the analysis to the period between 2009/2010 and 2012/2013

contribute to the understanding of the broadened scope and nature of academic entrepreneurship and investigated the ways in which the configuration of universities' institutional endowments of research and teaching affect diverse entrepreneurial ventures.

Universities have different sets of resources and capabilities depending on their organizational characteristics. They combine these assets partly as path dependent processes and partly as a response to a number of external factors-such as government policy, research funding, student market, and societal needs. In this paper, we empirically investigated the scope of academic entrepreneurship in terms of its links to research and teaching activities. Our results suggest, first, that the evolution of USOs and graduate startups exhibit two different pathways over time; and second, that both endowments in teaching and research affect entrepreneurial ventures but their effect is different.

Related to the first point, our results suggest that while the creation of USOs has been constant during the last years, there has been a considerable growth in the generation of graduate start-ups. Our empirical analysis shows the existence of two distinctive logics (manifested by teaching and research endowments) emerging across the English higher 
education sector over time. In relation to our hypotheses, both research and teaching play a role in determining the chances to create or grow an entrepreneurial venture. Particularly, stronger research endowments generate and nurture principally USOs creation but have a negative impact on the growth (turnover) of both spin-offs and graduate start-ups. On the other hand, teaching endowments seem to affect positively graduate start-ups turnover but negatively USOs'. Thus, in universities where the emphasis has been historically placed on acquiring and strengthening research endowments, the entrepreneurial behaviour will favour the generation of academic spin-offs in the short-term. Conversely, HEIs traditionally focused on teaching-related activities are better positioned to enable the success of student start-ups instead of academic spin-offs. Our results support the idea that the entrepreneurial knowledge required to promote business ventures is informed by both teaching and research activities (Shah and Pahnke 2014). However, we only partially support findings by Beyhan and Findik (2017) on the role of research in influencing students' ventures, and particularly by discussing separately the contribution of teaching and research endowments, we found that research endowments do not foster graduate entrepreneurship.

This study is an attempt to contribute to the empirical understanding of the diversity and complexity of academic entrepreneurial behaviour at the system level (see also, Kitagawa et al. 2016; Sánchez-Barrioluengo et al. 2016). The topic relates to HEIs' resource allocation decisions and has wider implications on the strategic resource management of universities, including reflections for higher education policy makers and funders alike. At the national higher education system level, our findings emphasize that universities are diverse. Individual HEIs generate different types of academic entrepreneurial ventures, conditioned by their strengths, historical contexts and external environments. Further questions remain with regards to institutional management and strategic choices: do universities have to choose between graduate start-ups and academic spin-offs activities? Is there a trade-off between these? And in what ways effective support mechanisms can be built to enhance a combination of teaching and research endowments to benefit both these activities? This in turn draws attention to the policy question of whether or not all universities should aspire to develop the same kind of academic entrepreneurship. At the university level, tensions may occur between strategic decisions regarding the types and levels of support for different academic entrepreneurship. As these competing value sets co-exist within the university, they also affect the shape and dynamics of the university's different missions and entrepreneurial outcomes.

It should be noted that university missions are interdependent-when particular emphasis is put on one mission that could affect, reinforce or decrease the others (SánchezBarrioluengo 2014). Individual level data on entrepreneurial activities would complement the picture depicted in this paper, providing better understanding of the internal characteristics and micro-processes of university entrepreneurship, as well as how individual actors-both academics and graduates - respond and evolve in relation to different organizational contexts, heterogeneous knowledge and capabilities creation processes (Ambos et al. 2008).

There are a number of limitations in this study. Due to the nature of the institutional data available in the HE-BCI, we did not look into the disciplinary differences of academic entrepreneurship activities. Better understanding on the internal differences between types of university entrepreneurship; such types in diverse organisational contexts (e.g. disciplinary differences) and resources (such as internal support mechanisms and access to external investment) are required. 
Finally, as well as within universities, it should be noted that competing values and drivers exist within graduate start-ups and USOs as organizations. Most USOs are market driven in nature, whilst their growth strategies and entrepreneurial characteristics may change over time. Their links and relationships with the university also changes. In the case of graduate start-ups, some may be driven by socially motivated objectives while others may be commercially driven. Universities may support student start-ups within the teaching and learning contexts, whilst the nature of the student venture may change over the time. More broadly, the implications for longitudinal strategies of sustainable and successful venture creation and the effectiveness of the support mechanisms provided by HEIs, need to be further understood in the light of the different contribution of teaching and research activities to academic entrepreneurship.

Acknowledgements Preliminary drafts of this paper were presented at the following workshop and conferences: "Academic Entrepreneurship and Knowledge and Technology Transfer: How do they relate to Research, Teaching, and Universities as Organization?" University of Kassel, Germany, (April, 2016); the EURKIND Conference in Valencia, Spain (June 2016); and Regional Innovation Policies Conference in Cardiff, the UK, (November 2016). We are grateful to the participants who provided comments and suggestions. We also wish to thank both the anonymous reviewers and the editor for the helpful comments provided. The views expressed in this paper are purely those of the authors and may not in any circumstances be regarded as stating an official position of the European Commission.

Open Access This article is distributed under the terms of the Creative Commons Attribution 4.0 International License (http://creativecommons.org/licenses/by/4.0/), which permits unrestricted use, distribution, and reproduction in any medium, provided you give appropriate credit to the original author(s) and the source, provide a link to the Creative Commons license, and indicate if changes were made.

\section{References}

Abreu, M., Demirel, P., Grinevich, V., \& Karatas-Ozkan, M. (2016). Entrepreneurial practices in researchintensive and teaching-led universities. Small Business Economics, 47(3), 695-717.

Abreu, M., \& Grinevich, V. (2013). The nature of academic entrepreneurship in the UK: Widening the focus on entrepreneurial activities. Research Policy, 42(2), 408-422.

Abreu, M., Grinevich, V., Hughes, A. \& Kitson, M. (2009). Knowledge exchange between academics and business, public and the third sector. Cambridge, UK: UK Innovation Research Centre.

Ambos, T. C., Mäkelä, K., Birkinshaw, J., \& D’Este, P. (2008). When does university research get commercialized? Creating ambidexterity in research institutions. Journal of Management Studies, 45, 1424-1447.

Astebro, T., Bazzazian, N., \& Braguinsky, S. (2012). Start-ups by recent university graduates and their faculty: Implications for university entrepreneurship policy. Research Policy, 41(4), 663-677.

Audretsch, D. (2014). From the entrepreneurial university to the university for the entrepreneurial society. Journal of Technology Transfer, 39(3), 313-321.

Béchard, J.-P., \& Grégoire, D. (2005). Entrepreneurship education research revisited: The case of higher education. Academy of Management Learning and Education, 4, 22-43.

Bercovitz, J., \& Feldman, M. (2006). Entpreprenerial universities and technology transfer: A conceptual framework for understanding knowledge-based economic development. The Journal of Technology Transfer, 31(1), 175-188.

Bergmann, H., Hundt, C., \& Stanberg, R. (2016). What makes student entrepreneurs? On the relevance (and irrelevance) of the university and the regional context for student start-ups. Small Business Economics, 47(1), 53-76.

Bertanha, M., \& Moser, P. (2016). Spatial errors in count data regressions. Journal of Econometric Methods, 5(1), 49-69.

Beyhan \& Findik (2017) Student and graduate entrepreneurship: Ambidextrous universities create more nascent entrepreneurs. Journal of Technology Transfer. 
BIS. (2013). Enterprise education impact in higher education and further education. https://www.gov.uk/ government/uploads/system/uploads/attachment_data/file/208715/bis-13-904-enterprise-education-impactin-higher-education-and-further-education.pdf

Braunerhjelm, P., \& Helgesson, C. (2006). The emergence of a European biotechnology cluster: The case of Medicon Valley. In P. Braunerhjelm \& M. Feldman (Eds.), Cluster genesis. Oxford: Oxford University Press e-book.

BUFDG: British Universities Finance Directors Group. (2013). The transparent approach to costing (TRAC): A short introductory guide for senior managers and governors.

Calzonetti, F. J., Miller, D. M., \& Reid, N. (2012). Building both technology-intensive and technologylimited clusters by emerging research universities: The Toledo example. Applied Geography, 34, 265-273.

Cameron A. C., \& Trivedi P. K. (2001). Essentials of count data regression. In Baltagi B. H. (Eds.) A companion to theoretical econometrics. Blackwell Companions to contemporary economics. Malden, MA: Blackwell Publishing Ltd.

CIHE/NCGE/NESTA. (2008). Developing Entrepreneurial Graduates-Putting entrepreneurship at the centre of higher education. www.ncee.org.uk/wp-content/.../developing_entrepreneurial_graduates.1. pdf. Accessed 30 Apr 15

Colyvas, J. A., \& Powell, W. W. (2007). From vulnerable to venerated: The institutionalization of academic entrepreneurship in the life sciences. In Lounsbury, M. (Ed.) The sociology of entrepreneurship, research in the sociology of organizations (pp. 219-259). Bingley: Emerald Group Publishing Limited.

D'Este, P., \& Patel, P. (2007). University-industry linkages in the UK: What are the factors underlying the variety of interactions with industry? Research Policy, 36(9), 1295-1313.

Damsgaard, E. F., \& Thursby, M. C. (2013). University entrepreneurship and professor privilege. Industry and Corporate Change, 22(1), 183-218.

Dodd, S. D., \& Hynes, B. (2012). The impact of regional educational contexts upon enterprise education. Entrepreneurship \& Regional Development, 24(9-10), 741-766.

DTI. (1998). Our competitive future: Building the knowledge-driven economy. London: Her Majesty's office.

Eisenhardt, K. M., Brown, S. L., \& Neck, H. M. (2000). Competing on the entrepreneurial edge. In G. D. Meyer \& K. A. Heppard (Eds.), Entrepreneurship as strategy (pp. 49-62). Thousand Oaks, CA: Sage.

European Commission. (2006). Entrepreneurship education in Europe: Fostering entrepreneurial mindsets through education and learning. Oslo October 2006. http://ec.europa.eu/enterprise/policies/sme/ promoting-entrepreneurship/education-training-entrepreneurship/policy-framework/2006-conference/ index/en.htm

European Commission. (2012). Effects and impact of entrepreneurship programmes in higher education. Brussels.

European Commission. (2015). Entrepreneurship education: A road to success-a compilation of impact of entrepreneurship education strategies and measures. Brussels: EC.

Fayolle, A. (2006). Assessing the impact of entrepreneurship education programmes: A new methodology. Journal of European Industrial Training, 30(9), 701-710.

Fayolle, A. (2013). Personal views on the future of the entrepreneurship education. Entrepreneurship \& Regional Development, 25(7/8), 692-701.

Feldman, M., \& Desrochers, P. (2004). Truth for its own sake: Academic culture and technology transfer at Johns Hopkins University. Minerva, 42(2), 692-701.

Geuna, A., \& Muscio, A. (2009). The governance of university knowledge transfer: A critical review of the literature. Minerva, 47(1), 93-114.

Global Entrepreneurship Monitor (GEM). (2012). Global Entrepreneurship Monitor 2012 Global Report. http://www.gemconsortium.org/docs/download/2645

Goldstein, H. (2010). The 'entrepreneurial turn' and regional economic development mission of universities. Annals of Regional Science, 44, 83-109.

Gouriéroux, C., Monfort, A., \& Trognon, A. (1984). Pseudo maximum likelihood methods: Application to Poisson models. Econometrica, 52(3), 701-720.

Greene, F. J., \& Saridakis, G. (2008). The role of higher education skills and support in graduate selfemployment. Studies in Higher Education, 33(6), 653-672.

Grimaldi, R., Kenney, M., Siegel, D. S., \& Wright, M. (2011). 30 years after Bayh-Dole: Reassessing academic entrepreneurship. Research Policy, Special Issue: 30 Years After Bayh-Dole: Reassessing Academic Entrepreneurship, 40, 1045-1057.

Guerrero, M., \& Urbano, D. (2012). The development of an entrepreneurial university. The Journal of Technology Transfer, 37(1), 43-74. 
Guerrero, M., Urbano, D., \& Fayolle, A. (2016). Entrepreneurial activity and regional competitiveness: Evidence from European entrepreneurial universities. The Journal of Technology Transfer, 41(1), $105-131$.

Harrison, R. T., \& Leitch, C. (2010). Voodoo institution or entrepreneurial university? Spin-off companies, the entrepreneurial system and regional development in the UK. Regional Studies, 44, 1241-1262.

Healey, A., Perkmann, M., Goddard, J., \& Kempton, L. (2014) Measuring the impact of university-business cooperation. (EAC/23/2012) Final Report.

HEFCE. (2015). Higher education-business and community interaction survey. Information accessed at: http://www.hefce.ac.uk/kess/hebci/

HEFCE. (2017). Higher education-business and community interaction survey. http://www.hefce.ac.uk/ke/ hebci/

Heher, A. D. (2006). Return on investment in innovation: Implications for institutions and national agencies. The Journal of Technology Transfer, 31(4), 403-414.

HESA. (2015). Definitions: HE business and community interaction. https://www.hesa.ac.uk/support/ definitions/hebci

Hewitt-Dundas, N. (2012). Research intensity and knowledge transfer activity in UK universities. Research Policy, 41(2), 262-275.

HM Treasury and BERR. (2008). Enterprise: Unlocking the UK's talent, March, 2008.

Honig, B. (2004). Entrepreneurship education: Toward a model of contingency-based business planning. Academy of Management Learning and Education, 3, 258-273.

Hsu, D. H., Roberts, E. B., \& Eesley, C. E. (2007). Entrepreneurs from technology-based universities: Evidence from MIT. Research Policy, 36, 768-788.

Huyghe, A., \& Knockaert, M. (2015). The influence of organizational culture and climate on entrepreneurial intentions among research scientists. The Journal of Technology Transfer, 40, 138-160.

Ireland, R. D., Covin, J. G., \& Kuratko, D. F. (2009). Conceptualizing corporate entrepreneurship strategy. Entrepreneurship Theory and Practice, 33, 19-46. doi:10.1111/j.1540-6520.2008.00279.x.

Ismail, K., Mason, C., Cooper, S., Omar, W., \& Majid, I. (2010). University Spin-off Formations: How decision making process has been made? International Journal of Business and Social Science, 1(2), $103-123$.

Kitagawa, F., \& Lightowler, C. (2013). Knowledge exchange: A comparison of policy, incentives and funding mechanisms in English and Scottish Higher Education. Research Evaluation, 22(1), 1-14.

Kitagawa, F., Sánchez-Barrioluengo, M., \& Uyarra, E. (2016). Third mission as institutional strategies: Between isomorphic forces and heterogeneous pathways, science and public policy. Science and Public Policy, 43(6), 736-750.

Kuratko, D. F. (2005). The emergence of entrepreneurship education: Development, trends, and challenges. Entrepreneurship Theory and Practice, 29, 577-598.

Lambert, R. (2003). Lambert review on business university collaboration. London: HMSO.

Leitch, C., Hazlett, S.-A., \& Pittaway, L. (2012). Entrepreneurship education and context. Entrepreneurship and Regional Development, 24(9/10), 733-740.

Lester, R. (2005). Universities, innovation, and the competitiveness of local economies, a summary report from the local innovation systems project-phase I. Cambridge: Industrial Performance Centre, Massachusetts Institute of Technology.

Libecap, G. D. (2005). University entrepreneurship and technology transfer: Process, design, and intellectual property. Amsterdam: Elsevier.

Link, A. N., \& Scott, J. T. (2005). Opening the ivory tower's door: An analysis of the determinants of the formation of US university spin-off companies. Research Policy, 34(7), 1106-1112.

Link, A. N., Siegel, D. S., \& Wright, M. (Eds.). (2014). The Chicago handbook of university technology transfer and academic entrepreneurship. Chicago, IL: University of Chicago Press.

Lockett, A., Siegel, D., Wright, M., \& Ensley, M. D. (2005). The creation of spin-off firms at public research institutions: Managerial and policy implications. Research Policy, 34(7), 981-993.

Lockett, A., Vohora, A., \& Wright, M. (2003). Universities; Strategies in the spinning-out of high technology companies. In Entrepreneurship research conference (pp. 1-15). Babson College: Kaufman Foundation.

Lockett, A., \& Wright, M. (2005). Resources, capabilities, risk capital and the creation of university spin-out companies. Research Policy, 34(7), 1043-1057.

Markman, G. D., Siegel, D. S., \& Wright, M. (2008). Research and technology commercialization. Journal of Management Studies, 45(8), 1401-1423.

Mars, M., Slaughter, S., \& Rhodes, G. (2008). The state-sponsored student entrepreneur. The Journal of Higher Education, 79(6), 638-670. 
Mowery, D. C., Nelson, R. R., Sampat, B. N., \& Ziedonis, A. A. (2001). The growth of patenting and licensing by US universities: An assessment of the effects of the Bayh-Dohl Act of 1980. Research Policy, 30, 99-119.

Mowery, D., \& Sampat, B. N. (2005). Universities in national innovation systems. In J. Fagerberg, D. Mowery, \& R. R. Nelson (Eds.), The Oxford handbook of innovation (pp. 209-239). Oxford: Oxford University Press.

Niosi, J. (2006). Success factors in Canadian academic spin-offs. The Journal of Technology Transfer, 31, $451-457$.

O'Shea, R. P., Allen, Chavalier, \& Roche, F. (2005). Entrepreneurial orientation, technology transfer and spinoff performance of U.S. universities. Research Policy, 34, 994-1009.

Ocasio, \& Radoynovska, (2016). Strategy and commitments to institutional logics: Organizational heterogeneity in business models and governance. Strategic Organization, 14(4), 287-309.

Perkmann, M., King, Z., \& Pavelin, S. (2011). Engaging excellence? Effects of faculty quality on university engagement with industry. Research Policy, 40, 539-552.

Powell, W. W., \& Colyvas, J. A. (2008). Microfoundations of institutional theory. In R. Greenwood, C. Oliver, K. Sahlin, \& R. Suddaby (Eds.), The Sage handbook of organizational institutionalism. London: Sage.

Rasmussen, E., Mosey, S., \& Wright, M. (2011). The evolution of entrepreneurial competencies: A longitudinal study of university spin-off venture emergence. Journal of Management Studies, 48(6), $1314-1345$.

Rossi, F. (2009). Increased competition and diversity in higher education: An empirical analysis of the italian university system. Higher Education Policy, 22, 389-413.

Rossi, F., \& Rosli, A. (2015). Indicators of university-industry knowledge transfer performance and their implications for universities: Evidence from the United Kingdom. Studies in Higher Education, 40(10), 1970-1991.

Rothaermel, F. T., Agung, S. D., \& Jiang, L. (2007). University entrepreneurship: A taxonomy of the literature. Industrial and Corporate Change, 16(4), 691-791.

Sánchez-Barrioluengo, M. (2014). Articulating the 'three missions' in Spanish universities. Research Policy, 43(10), 1760-1773.

Sánchez-Barrioluengo, M., Uyarra, E., \& Kitagawa, F. (2016) The evolution of triple helix dynamics. The Case of English Higher Education, CIMR Research Working Paper http://www.bbk.ac.uk/innovation/ publications/docs/WP32.pdf. Accessed 10 Dec 16

Shah, \& Pahnke, (2014). Parting the ivory curtain: Understanding how universities support a diverse set of startups. Journal of Technology Transfer, 39(5), 780-792.

Shane, S. A. (2004). Academic entrepreneurship: University spinoffs and wealth creation. Cheltenham: Edward Elgar Publishing.

Siegel, D. S., Veugelers, R., \& Wright, M. (2007a). Technology transfer offices and commercialization of university intellectual property: Performance and policy implications. Oxf ord Review of Economic Policy, 23, 640-660.

Siegel, D., Waldman, D., \& Link, A. N. (2003). Assessing the impact of organizational practices on the productivity of university technology transfer offices: An exploratory study. Research Policy, 32(1), $27-48$.

Siegel, D., \& Wright, M. (2015). Academic entrepreneurship: Time for a re-think? British Journal of Management, 26(4), 582-595.

Siegel, D. S., Wright, M., \& Lockett, A. (2007b). The rise of entrepreneurial activity at universities: Organizational and societal implications. Industrial and Corporate Change, 16(4), 489-504.

Smith, K. (2015). Measuring the impact of enterprise education and entrepreneurship support in higher education: Can routinely collected data be of use? Industry and Higher Education, 29(6), 493-503.

van Vught, F. (1996). Isomorphism in higher education? Towards a theory of differentiation and diversity in higher education systems. In V. L. Meek, L. Goedegebuure, O. Kivinen, \& R. Rinne (Eds.), The mockers and the mocked: Comparative perspectives on differentiation, convergence and diversity in higher education (pp. 42-57). Oxford: Pergamon.

van Vught, F. (2008). Mission diversity and reputation in higher education. Higher Education Policy, 21(2), $151-174$.

Walter, S. G., \& Dohse, D. (2012). Why mode and regional context matter for entrepreneurship education. Entrepreneurship \& Regional Development, 24, 807-835. doi:10.1080/08985626.2012.721009.

Wooldridge, J. M. (1999). Quasi-likelihood methods for count data. In M. H. Pesaran \& P. Schmidt (Eds.), Handbook of Applied Econometrics Volume II: Microeconomics. Oxford: Blackwell.

Wooldridge, J. M. (2010). Econometric analysis of cross section and panel data. Cambridge: MIT Press. 
Wright, M. (2014). Academic entrepreneurship, technology transfer and society: Where next? The Journal of Technology Transfer, 39, 322-334.

Wright, M., Clarysse, B., Mustar, P., \& Lockett, A. (2007). Academic entrepreneurship in Europe. Cheltenham: Edward Elgar.

Young, D. (2014) Enterprise for all. https://www.gov.uk/government/uploads/system/uploads/attachment_ data/file/338749/EnterpriseforAll-lowres-200614.pdf 